\title{
ESTUDANTES E INTELECTUAIS DO PCB: A LUTA POR LIBERDADES DEMOCRÁTICAS DURANTE A DITADURA
}

\author{
Aguinaldo Rodrigues Gomes \\ Doutor em Educação pela UNICAMP/ Docente do departamento de História do \\ Campus de Rondonópolis da Universidade Federal de Mato Grosso. \\ aguinaldorod@gmail.com
}

\begin{abstract}
resumo: A discussão da resistência de intelectuais e estudantes do PCB ao regime ditatorial, aqui, insere-se no recente debate historiográfico acerca do tema, que tem buscado pensar como esse acontecimento político, um dos mais dramáticos de nossa história, repercutiu fora dos centros de poder do Brasil eixo Rio-São Paulo. Portanto, a ênfase recairá sobre as estratégias do PCB na construção de uma luta pelos diretos civis no campo educacional por parte de estudantes e professores que ousaram enfrentar o regime em defesa das liberdades de expressão.
\end{abstract}

palavras-chave: Ditadura, Direitos Humanos, Educação; Intelectuais. abstract: The discussion concerning the resistance of intelectuals and studants from the PCB to the dictatorial regime, In here, it is added to the recent historiagraphic debate around its theme which has been trying to pursue this as a political event, one of the most dramatic of out History, took place outside of the major centers of power from Brazil - axis focused on Rio-São Paulo. Therefore, the enfasis falls upon the strategies of PCB on the construction of a fight for civil rights on the educational field lead by teachers and studants who dared to face the regime in order to get and defend freedom of speech.

keywords: Dictatorship, Humans Rights, Education; Intelectuals. 
a visão educacional do $p c b$ - a construção da contra-hegemonia

recisambs frisar que, se de um lado tivemos todas as inciativas das entidades empresariais ${ }^{1}$ para a construção de uma sociedade e uma educação conservadoras por meio do financiamento de obras, seminários e publicações, de outro tivemos uma contraproposta formulada no interior do PCB. Num documento intitulado A ção $p$ olítica, elaborado em 1965 para analisar o golpe de 1o de abril de 1964, que modificou a situação política nacional, encontramos na resolu ção $\mathrm{n}$ - 1uma primeira referência à concepção de educação defendida pelo PCB.É importante destacar que na referida resolução os dirigentes entendem o golpe de 1964 como um movimento de forças retrógadas e antinacionais que ganharam força a partir da propaganda antijanguista e anticomunista de agentes do imperialismo norte-americano, latifundiários e grandes capitalistas ligados aos monopólios ianques. Ou seja, criouse um governo exercido por um grupo de generais a serviço da embaixada dos Estados Unidos.

Dessa forma, a primeira visão defendida pelo PCB é a da educação como um campo de resistência ao regime, no qual estudantes e intelectuais têm um papel primordial no enfrentamento do regime ditatorial. A ssim se referia o partido ao movimento estudantil e ao campo educacional naquele contexto: "Os estudantes se insurgem contra a Lei 4464, em defesa da autonomia do movimento estudantil, na

\footnotetext{
${ }^{1}$ Segundo Luiz Antônio Cunha: Os intelectuais orgânicos da classe dominante atuavam no Congresso Nacional, formavam opinião pública através dos meios de comunicação de massas, da escola, de parte das igrejas, de organizações tipo IPES (Instituto de Pesquisas e Estudos Sociais) e IBAD (Instituto Brasileiro de Ação Democrática), instrumentalizando conceitos ideológicos de "civilização ocidental e cristã", corrompendo com dinheiro da embaixada americana (eleiçỗes de 1962) com o objetivo político de conservação das estruturas, contra as reformas ou qualquer mudança, escamoteando a discussão da luta de classes (CUNHA, 1994, p. 9). Sobre isso consultar: CUNHA, Luís Antônio; GÓES, Moacyr. O golpe na educação. Rio de Janeiro: Jorge Zahar Editor, 1994.
}

\footnotetext{
Gomes,. R. Estudantes e intelectuais do FCB: a luta por liberdades democráticas durante a ditadura.

albuquerque: revista de historia. vol. 9, n. 17, jan.-jul. de 2017, p. 94-116
} 
UNE e das suas demais entidades" (RESOLUÇÃO POLÍTICA do Comitê Central do Partido Comunista Brasileiro, 1965, p.19).?

A lei, assinada pelo presidente Castelo Branco e por Flávio Lacerda, dispunha sobre a regulamentação das atividades de representação estudantil.Conhecida como Lei Suplicy, representava o fechamento das entidades estudantis, através da criação de órgãos como o Diretório N acional de Estudantes (DNE) e os Diretórios Estaduais de Estudantes (DEEs). Dessa forma, abria caminho para a substituição da UNE (União N acional dos Estudantes) e das UEEs (União Estadual dos Estudantes). Em 1967, mesmo com vários protestos estudantis contra essa resolução, o governo lançou o Decreto-Lei n.228, que extinguia esses órgãos, deixando os estudantes sem nenhuma entidade representativa legal eà mercê dos desmandos dos ditadores.U m dos artigos principais da lei, que demonstrava o que os militares pensavam sobre a finalidade dos órgãos de representação estudantil, estava expresso no item d) de seu artigo o:

\begin{abstract}
Art. I Os órgãos de representação dos estudantes de ensino superior, que se regerão por esta Lei, têm por finalidade: organizar reuniões e certames de caráter cívico, social, cultural, científico, técnico, artístico, e desportivo, visando à complementação e ao aprimoramento da formação universitária (Coleção de Leis do Brasil - 1964, V ol. 7, p. 75).
\end{abstract}

A intenção era clara: diminuir a influência subversiva no interior das entidades estudantis e promover o civismo e o patriotismo desse espaço por meio de seu esvaziamento político. Mas esse objetivo não foi alcançado tão facilmente ea Lei Suplicy de Lacerda acabou despertando muitas reações contrárias, mesmo de apoiadores do golpe que, embora fossem contra o aparelhamento comunista no comando das entidades, defendiam o direito de livre organização por parte dos estudantes. A resolução trata ainda de uma dimensão da educação como fruição cultural, como forma de preservar a liberdade democrática de expressão de ideias artísticas e políticas. "Os intelectuais se arregimentam contra o terror cultural e para exigir a restauração das liberdades democráticas e a retomada do desenvolvimento econômico do país" (RESOLUÇÃ POLÍTICA do Comitê Central do Partido Comunista Brasileiro, 1965, p. 19).

\footnotetext{
${ }^{2}$ Cumpre esclarecer que todos os documentos do PCB que utilizaremos na tese foram retirados de CARONE, Edgard. O P.C.B. (1964-1982). São Paulo: Difel, 1982. Vol. 3. Por esse motivo decidimos listar as referências completas dos documentos nas notas de rodapé. Voz operária, Suplemento Especial, Resolução do Comitê Central do Partido Comunista Brasileiro, maio de 1965. In: CARONE, Edgard. O P.C.B. (19641982). São Paulo: Difel, 1982, p. 19.
} 
Rodrigo Czajka (2010), apoiando-se em Sodré (1963), assim se refere à relação entre política, intelectuais e cultura no contexto de J oão Goulart:

Daí que a participação política e o engajamento de intelectuais e artistas estavam condicionados à construção de um referencial de cultura popular que também fosse nacional. Era necessário constituir um referencial popular a partir da cultura, pois por meio dele seria possível contemplar o "povo" no interior de uma política voltada para a transformação da realidade nacional (SO DRÉ, 1963, p. 25).

A inda segundo Czajka, o que se buscava era uma democratização não só do acesso aos bens sociais, mas também dos bens culturais no contexto dos anos 1960, sobretudo após as propostas de reforma de João Goulart:

\begin{abstract}
Essa nova condição permitiu compor um amplo quadro de lutas sociais, engendradas pelas novas condições de organização política e ideológica das organizações de esquerda, contra as "estruturas arcaicas"de uma sociedade que avançava aos poucos, no sentido da democratização dos bens sociais e culturais. Assim, em consonância com a política cultural do PCB, "no pré-64, o nacional, correlato da luta anti-imperialista, reivindicava a afirmação de uma arte não-alienada que refletisse a realidade brasileira que se queria conhecer para transformar. 0 popular, por sua vez, acenava paraa democratização da cultura e a conseqüente crítica à nossa tradição elitista de uma arte concebida como 'ornamento', como 'intimismo à sombra do poder" (CZAJJKA, 2010, p. 98).
\end{abstract}

A ssis Tavares, no documento sob o título de Causas da Derrocada de 10 de A bril de 1964, publicado na revista Civilização Brasileira em julho de 1966, também aponta o campo educacional e o movimento estudantil como protagonistas das forças progressistas no Brasil.A firma ele: N úcleos importantes das camadas médias, especialmente entre estudantes e a intelectualidade, assumiram, porém, nítida posição ao lado das forças progressistas. Foi impressionante a transformação da juventude de 1945 e 1964. Enquanto no fim da guerra a juventude estudantil apenas motivada pela luta em favor das liberdades de 1961 em diante ficou claro o engajamento da mocidade universitária no combate pelas modificações estruturais na sociedade brasileira. ${ }^{3}$

\footnotetext{
${ }^{3}$ TAVARES, Assis. Causas da Derrocada de $1^{\circ}$ de Abril de 1964, Revista Civilização Brasileira, Ano I, $\mathrm{n}^{\circ} 8$ julho de 1966) In: CARONE, Edgard. O P.C.B. (1964-1982). São Paulo: Difel, 1982, p. 44. 
Tavares, nesse trecho, explicita que, para ele, a partir do contexto do golpe, a juventude brasileira despertou sua consciência para lutas que extrapolavam a dimensão escolar e se envolveu com as questões políticas que atingiam o país naquele momento, demonstrando, assim, uma compreensão de educação que supera seu caráter instrumental, alcançando sua função formativa, humanista e transformadora. Talvez por esse motivo o PCB, em seu período de legalidade - 1945 a 1947 -, tenha sido um parceiro importante de intelectuais como Paschoal Leme na defesa da escola pública como forma de, por meio do conhecimento historicamente acumulado pela sociedade, almejar uma sociedade mais justa e equânime. Tavares reforça ainda mais a necessidade de a educação se voltar para a reflexão de questões extramuros, demostrando a dimensão social e política das instituições escolares. A inda se referindo aos estudantes, ele afirma:

\begin{abstract}
Passaram-se(sic) a exercer uma importanteinfluência política fora das escolas, tornando-se daquelas ideias ativos propagandistas. A reação procurou fazer crer que o grosso dos estudantes nada tinha a ver com tais atitudes, o que não confirmado pelos fatos posteriores, pós-"revolução", desde que a mocidade acadêmica sempre manifestou seu repúdio aos novos governantes do País.10
\end{abstract}

Se no campo da educação básica a situação era de um certo protagonismo, no meio universitário a resistência ficou a cargo de uma vanguarda, nem sempre seguida pela maioria dos estudantes universitários, que muitas vezes estava mais preocupada com questões internas à universidade.

\begin{abstract}
Entretanto, mesmo o movimento universitário ainda era a expressão de um grupo de vanguarda, não chegando a mobilizar a grande maioria dos estudantes. Claro que havia exceções nesse quadro. Em determinados lugares e em certas fases, o movimento estudantil chegou a expressar a grande massa universitária. N ormalmente, porém, as entidades estudantis estavam isoladas dessagrande massa, em virtude denão prestarem a devida atenção às questões que preocupam os universitários como universitários: problemas da modernização das escolas, bolsas de estudo, mercado de trabalho para os profissionais, jubilação, etc.4
\end{abstract}

Os documentos do PCB também nos esclarecem que o engajamento dos estudantes e intelectuais no pós-golpe se deu numa via de mão dupla, uma vez que tais grupos faziam críticas ao regime e recebiam as devidas represálias, o que, por

\footnotetext{
${ }^{4}$ Idem.
} 
vezes, acabava por aumentar a atuação antiditatorial de estudantes e intelectuais. Conforme se apura nos documentos, o golpe impôs um recuo evidente da vanguarda em nosso país.

\begin{abstract}
Embora dirigido fundamentalmente contra o movimento operário, o golpe voltou-se contra a maioria das organizações democráticas, tais como as associações camponesas e entidades estudantis, e contra personalidades políticas e intelectuais de destaque na luta patriótica; assim, com os sindicatos operários sob intervenção policial, e seus dirigentes presos ou perseguidos, com o conjunto das organizações de massa impedido deatuar, com seus aliados eamigos vitimados pela repressão gol pista, com a imprensa popular fechada ou amordaçada, o Partido ficou privado de seus principais meios de atuação política.5
\end{abstract}

Em função da repressão maciça ao PCB, foi necessário arregimentar forças em grupos sociais que atuavam fora do partido, uma vez que eram constantes as prisões e a marginalização das lideranças dos movimentos populares, espalhando o terror entre os trabalhadores e, portanto, levando a um recuo da participação do povo no processo de resistência ao regime. Assim, "coube, nesse sentido, papel destacado à intelectualidade em particular aos estudantes".6

No documento do VI Congresso do PCB, no item Nossa Tática, os dirigentes destacam novamente o papel preponderante dos intelectuais em defesa de uma cultura nacional:

O papel da intelectualidade progressista é de grande relevo no combate à ditadura. Os comunistas devem atuar como elemento de estímulo e unificação da luta dos intelectuais em defesa da cultura nacional, pela liberdade de pesquisa, de criação e pela manifestação do pensamento?

N ovamente encontramos nesse documento uma referência à importância da juventude no processo de luta contra a ditadura. No entanto, o centralismo democrático que buscava tutelar o movimento também se fazia presente:

\footnotetext{
${ }^{5}$ VI Congresso do P.C.B., 1967, p. 54.

${ }^{6}$ Idem, ibidem, p. 69.

${ }^{7}$ Idem, ibidem, p. 75.
} 
A participação da juventude na vida nacional tem significado crescente. Representan do mais da metade da população do país, e sendo por natureza mais sensível aos reclamos do futuro da nação, os jovens comunicam seu calor ás lutas do povo. A juventude estudantil tem participado de lutas valorosas contra o regime opressor, embora seus movimentos seressintam da influência, em sualiderança, de correntes sectárias. É preciso ganhar a maioria dos estudantes para esses combates, baseando-os mais solidamente na defesa das reivindicações peculiares a juventude escolar . $^{16}$

N ovamente nos causa estranheza o fato de o Comitê Central do partido acusar as lideranças estudantis de sectarismo e ainda restringir as lutas dos estudantes a questões particulares. É claro que temos conhecimento de que, do ponto de vista tático, essa era uma tentativa de ganhar o maior número possível de simpatizantes para a causa do partido, que era de massa. Consideramos que, ao restringir o escopo de atuação do movimento estudantil, o PCB acabava por despolitizálo. A resolução política do CE da Guanabara, publicada em 1970, estabelece al gumas diretrizes elinha de trabalhos que os militantes deveriam seguir para que a resistência à ditadura se tornasse efetiva. Dentre elas, destacamos a frente estudantil e a cultural:

Na frente Estudantil: luta para dar aos estudantes o direito de gerirem suas organizações e de realizarem livremente suas reuniões e assembleias nos locais de estudo; luta pela revogação do 477 e contra o terror dentro das Universidades e colégios; luta pela libertação dos estudantes presos.

Na frente Cultural: luta pela liberdade de criação e de pesquisa: resistência ao terror cultural e á censura ao trabalho de criação artística, de divulgação e de informação.

O Decreto-Lei n. 477, publicado em fevereiro de 1969 pelo governo de Costa e Silva, define as infrações disciplinares praticadas por professores, alunos, funcionários ou empregados de estabelecimentos de ensino públicos ou particulares com o objetivo de propagar o terror no interior das instituições. Em seu artigo primeiro, define o seguinte:

A rt ำ Comete infração disciplinar o professor, aluno, funcionário ou empregado de estabelecimento de ensino público ou particular

\footnotetext{
${ }^{8}$ Resolução Política do C.E. da Guanabara do PCB: março de 1970. Temas, n. 10, pp. 71-91.
} 
que:I - A licie ou inciteà deflagração de movimento que tenha por finalidade a paralisação de atividade escolar ou participe nesse movimento;

II - A tente contra pessoas ou bens tanto em prédio ou instalações, de qualquer natureza, dentro de estabelecimentos de ensino, como fora dêle;

III - Pratique atos destinados à organização de movimentos subversivos, passeatas, desfiles ou comícios não autorizados, ou dêle participe;

- Conduza ou realize, confeccione, imprima, tenha em depósito, distribua material subversivo de qualquer natureza;

- Seqüestre ou mantenha em cárcere privado diretor, membro de corpo docente, funcionário ou empregado de estabelecimento de ensino, agente de autoridade ou aluno;

- Use dependência ou recinto escolar para fins de subversão ou para praticar ato contrário à moral ou à ordem pública. 9

Os termos presentes demonstram a grande preocupação que 0 regime possuía com as atividades organizadas pelo movimento estudantil. A pontamos, a partir da documentação, os estudantes que, após o desmantelamento das organizações de trabal hadores, passaram a ser, juntamente com os intelectuais, os principais protagonistas da resistência. N esse contexto, toda ação, por mais simples que fosse, estava sob suspeita; uma simples reunião ou uma passeata poderia ser considerada ato subversivo. Considerase, ainda, o clima de terror que se espalhou entre professores, alunos e técnicos das instituições escolares, já que qualquer um poderia ser um delator, um censor do regime. Todo cuidado era pouco, pois as penas eram rigorosas e poderiam variar conforme o vínculo que o praticantetinha com a instituição, como observamos no caput do artigo anteriormente citado:

§ ำ A s infrações definidas neste artigo serão punidas:

- Se se tratar de membro do corpo docente, funcionário ou empregado de estabelecimento de ensino com pena de demissão ou dispensa, e a proibição de ser nomeado, admitido ou contratado por qualquer outro da mesma natureza, pelo prazo de cinco (5) anos;

\footnotetext{
${ }^{9}$ BRASIL, Decreto-Lei n. 477, de 26 de fevereiro de 1969. In: SANFELICE, José Luís. Movimento estudantil: a UNE na resistência ao golpe de 64. São Paulo: Cortez, 1986.p. 233. 
- Se se tratar de aluno, com a pena de desligamento, e a proibição de se matricular em qualquer outro, estabelecimento de ensino pelo prazo de três (3) anos.

$\S 2$ ㄴ Se o infrator fôr ben eficiário de bolsa de estudo ou perceber qualquer ajuda do Poder Público, perdêlazá, enão poderá gozar de nenhum dêsses benefícios pelo prazo de cinco (5) anos.

$\S 30$ Sese tratar de bolsista estrangeiro serásolicitada a sua imediata retirada de território nacional. ${ }^{10}$

Como ressaltaram José A ugusto Guilhon A lbuquerque (1977) e Sanfelice (1986), o objetivo do decreto era estabelecer um controle efetivo sobre o movimento estudantil e enfraquecer sua representatividade política junto aos alunos. Os autores apontam que além das medidas de repressão pura e simples, os militares ainda utilizaram dispositivos "legais", impetrados por meio de leis e decretos, para conter a resistência dos movimentos organizados dos estudantes. Tal aspecto repressivo desse período se torna ainda mais evidente no artigo segundo do referido decreto, no qual encontramos uma prática recorrente durante o regime militar - os IPMs - como forma de amedrontar e punir, de forma arbitrária, os cidadãos que atentassem contra o regime autoritário instituído no país.

A rt 2ำ A apuração das infrações a que se refere êste Decreto-lei far-seá mediante processo sumário a ser concluído no prazo improrrogável, de vinte dias.

Parágrafo único. Havendo suspeita de prática de crime, o dirigente do estabelecimento de ensino providenciará, desde logo a instauração de inquérito Policial.11

Como demonstra o artigo segundo, cabia ao dirigente do estabelecimento de ensino a função de instaurar do inquérito policial, o que evidencia que as acusações e apurações vinham dos próprios pares.

\footnotetext{
10 Idem.

11 Idem.
} 


\section{3}

o pcb e a educação do militante

Em texto publicado na revista Estudos, na data do 49 an aniversário do PCB, em março de 1971, intitulado A spectos da luta contra o subjetivismo, Luís Carlos Prestes demonstra sua preocupação com a formação intelectual dos militantes e dos simpatizantes do PCB.

O primeiro aspecto que consideramos importante no documento é a tentativa de Prestes de fazer uma discussão teórica das bases do marxismo para afastar o que denominava subjetivismo dos comunistas brasileiros, como se anuncia logo no trecho inicial do documento:

Os comunistas brasileiros, na luta histórica em que se acham empenhados pela democracia e pelo socialismo, enfrentam numerosas dificuldades, tanto práticas como teóricas. Entre estas, como reconheceu o último congresso de nosso Partido, estão "nossas limitações teóricas" e o "domínio insuficiente da realidade do país". Daí o subjetivismo que tantos males já nos causou, levando a equívocos, fal has eerros de consequências muitas vezes desastrosas para a luta sustentada pelo movimento operário que cabe aos comunistas orientar e dirigir.?

O que se evidencia nas palavras de Prestes é a dificuldade de os dirigentes e militantes entenderem, de forma adequada, a conjuntura brasileira a partir dos pressupostos da teoria materialista, que preconiza que análise deve ser feita com base na realidade concreta da sociedade, e não a partir de teorias prévias próprias do idealismo. Como deixa implícito o autor, muitos erros foram cometidos pelo partido em função da tran sposição de experiências de outras real idades sociais e econômicas que não se aplicavam ao contexto brasileiro. Um dos exemplos que poderíamos destacar é a visão mecânica e etapista que o partido e seus dirigentes possuíam da teoria da revolução elaborada por Marx a partir do contexto especifico do século XIX na Europa. A aplicação mecânica do marxismo sem maiores reflexões levou o partido a buscar aliados em parceiros duvidosos, como a burguesia nacionalista, que embora fosse crítica do imperialismo e dos grandes latifúndios, jamais se tornaria adepta do comunismo preconizado pelo PCB. Prestes se referia a esse erro teórico da seguinte maneira:

\footnotetext{
12 PRESTES, Luiz Carlos. Aspectos da Luta Contra o Subjetivismo no $49^{\circ}$ aniversário do PCB. Estudos, Ano I, n. 2, março de 1971, p. 108.
} 
Refiro-me á tendência á transposição mecânica a nosso país da experiência de outros povos. Posição dogmática e, portanto, antimarxista e antileninista, mas que, no entanto, vem-se repetindo em nossas fileiras, servindo de cobertura para as tendências oportunistas, tanto de direita como de esquerda. ${ }^{13}$

Parece-nos necessário destacar que Prestes considera esse um problema educacional, ou seja, a formação intelectual insuficiente e/ou mesmo equivocada da grande maioria da sociedade, por influência de uma cultura burguesa ou pequenoburguesa de alguns militantes, seria o que levaria ao equívoco de tal monta, como aponta em outro trecho de seu texto:

Um fosso profundo separa, em nosso país, a minoria letrada da maioria esmagadora da nação-miserável, em grande parte analfabeta, e brutalmente explorada e oprimida. Contraste que se agrava com o crescente monopólio imperialista dos meios de comunicação em massa e com a censura oficial, burocrática e reacionária. ${ }^{14}$

Novamente a preocupação com a função dos intelectuais como fomentadores deuma nova instrução educacional ecultural sefaz presenteem suas palavras:

Isto não significa negar o esforço patriótico e honesto dos intelectuais brasileiros, que vão forjando, ao lado e em oposição á chamada cultura nacional, reacionária e dominante, porque éa das classes dominantes, uma cultura progressista e popular, com elementos democráticos e socialistas. São grandes, no entanto, as dificuldades que enfrentam os intelectuais em nosso país para refletir e expressar o que se passa entre o povo, seus sentimentos e reivindicações, e, daí, a tendên cia à cópia, átransposição mecânica de manifestações alienígenas, ao cosmopolitismo cultural..$^{5}$

\footnotetext{
13 Idem.

${ }^{14}$ Idem, ibidem, p. 109.

15 Idem.
} 
A poiando-se nos dizeres de Mário de A ndrade, intelectual engajado na busca de uma cultura brasileira, Prestes continua suas críticas à importação de ideias externas para o processo de educação no Brasil.

Combato atualmente a Europa - dizia Mario de A ndrade, em 1942 - mais que posso. Não porque deixe de reconhecêla, admirála, porém, para destruir a europeização do "brasileiro educado." Mas, como não foi modificada a estrutura sócio-econômica do país, essa destruição não foi possível. "A europeização" transformou-se em americanização do "Brasileiro educado" .16

Segundo Prestes, essa tendência à imitação de teorias que não se aplicam ao contexto do Brasil dos anos 1960, motivada pela pouca instrução do povo brasileiro ou mesmo por leituras aligeiradas da teoria marxista por militantes da ultraesquerda, foi o que levou aos insucessos da luta armada no país, uma vez que se pretendeu aplicar aqui um processo revolucionário nos moldes da revolução cubana. Sobre isso, afirma ele:

\begin{abstract}
Mas, como advertia Lenine, é indispensável na aplicação dos princípios fundamentais do comunismo, tomar em consideração as particularidades específicas de cada nação. Olvidar as peculiaridades nacionais édivorciarse da vida edas massas, énegar a ciência do proletariado. Foi esquecendo esses princípios do marxismo-leninismo que se tentou transpor para nosso país a experiência vitoriosa do povo cubano, em geral reduzida, de maneira caricata, aos aspectos da luta armada sustentada por um pequeno grupo de guerrilheiros, sem tomar em consideração numerosos outros fatores - econômicos, políticos, sociais e culturais - específicos de cuba equecontribuíram para a vitória da revolução na ilha da Liberdade. E, justamente com isto, levantava se em nosso país a bandeira da luta armada, da criação de "focos" guerrilheiros isolados das massas, sem cuidar do estudo ou do exame da situação concreta brasileira, dos diversos fatores que conforma essa situação. ${ }^{17}$
\end{abstract}

Prestes, assim como a maioria da direção do PCB, considerava a iniciativa da luta armada um caminho pouco adequado para a deflagração de uma revolução no Brasil. Para ele, essa ideia configurava-se numa posição sectária de um pequeno

\footnotetext{
16 Idem.

17 Idem, ibidem, p. 110.
} 
grupo ultraesquerdista que atrapalhava o processo, na medida em que justificava ataques cada vez mais violentos por parte dos militares contra os oposicionistas. Em sua visão, tal ação servia apenas para intensificar o aniquilamento físico de vários "revolucionários, jovens patriotas, abnegados e valentes."18 De certa forma, Prestes, com essas críticas, explicitava sua divergência não só com a luta armada, mas também com processos revolucionários comandados por militares "pequenoburgueses" ou mesmo pela burguesia nacional. "A experiência dos últimos quarenta anos já nos ensinou que não é sob a direção dos militares pequeno-burgueses nem da burguesia nacional que poderá avançar o processo revolucionário em nosso país" (A spectos da Luta Contra o Subjetivismo no 49.9 aniversário do PCB, p. 117).19.

Prestes aponta os problemas de nosso passado colonial, a exemplo do sistema imperial adotado aqui, como um dos motivos do nosso atraso cultural. Citando Berlinck, ele afirma: "a origem das nossas deficiências (analfabetismo, baixa produtividade, opressão política) e que se podem resumir na formula: falta de valorização do homem brasileiro, provém da nossa formação colonial"20

Segundo Prestes, nossas escolas ainda ensinam uma história comprometida com os interesses dos setores conservadores. A luta heroica dos oprimidos geralmente não é objeto de estudo nem da historiografia oficial, nem mesmo dos programas escolares que, quase sempre, buscam tratar os processos de mudança de forma linear e pacífica. Sobre o sentido dado pela escola à história de nosso país, pronunciava ele:

\begin{abstract}
A título dehistória, propagam-se as mais cínicas mentiras ebastou queno ISEB fosse feita uma primeira etímida ten tativa no sentido de ser reescrita a história do país com base em pesquisa menos comprometida com os interesses dos setores mais retrógados das classes dominantes para que seus autores fossem processados juridicamente sob acusação de atentarem contra a segurança nacional? ${ }^{21}$
\end{abstract}

Finalizando seu documento contra o subjetivismo no interior do partido comunista, Prestes nos esclarece qual era, para ele, o papel da educação no interior da sociedade brasileira e do partido. Para ele, além de uma convicção revolucionária, era preciso intensificar a educação teórica dos militantes por meio do estudo sistemático do marxismo-leninismo. 0 autor assim finaliza sua reflexão:

\footnotetext{
18 Idem.

${ }^{19}$ Idem, ibidem, p.111.

${ }^{20}$ Idem, ibidem, p. 114.

${ }^{21}$ Idem, ibidem, p 115.
} 
Será esta a oportunidade de concentrarmos esforços no sentido do estudo científico da realidade brasileira, que não pode deixar de incluir o estudo das condições em que se desenvolve o capitalismo em nosso pás, a história de nosso povo, a do movimento operário brasileiro ea indústria de nosso próprio partido.22

Em um documento publicado no jornal Voz Operária, em 1971, que tratava das tarefas do Comitê Central, encontramos, além da preocupação com a educação militante e com a educação em geral como forma de permitir uma compreensão da realidade brasileira, a defesa feita pelo partido de um movimento estudantil livre, de escolas e universidades gratuitas a partir de um aumento das vagas e da proibição de cobrança de mensalidades nessas instituições. $\mathrm{N}$ o item 5 do referido documento, encontramos os seguintes dizeres:

5- Devemos dar maior contribuição à reativação do movimento estudantil, à base da luta pela am pliação das vagas escolares, contra o aumento das anuidades escolares, contra a instituição do ensino pago nas universidades oficiais, contra o Decreto 477 e o terror estabelecido nas escolas, pelo direito de os estudantes se organizarem livremente, pela solidariedade aos estudantes e professores presos e perseguidos e pela R eforma U niversitária. ${ }^{23}$

Como já apontamos no início dessa reflexão,édifícil tratar deuma concepção educacional do PCB, uma vez que, como apontou Favoreto, foi a

concepção de revolução que guiou o PCB em suas ações educacionais ena luta pela escola pública.A inda de acordo com ela, a teoria da revolução brasileira foi um programa de transformação das estruturas da sociedade, em meio à qual, com base em sua concepção de história e partido, foi construído seu entendimento da relação entre a questão educacional e o processo histórico (FA V ORETO, 2010, p. 129).

No capítulo dedicado à educação militante, a autora busca destacar como a concepção de revolução interna ao PCB traça a relação entre a teoria social, a

\footnotetext{
22 Idem, ibidem, p. 120.

${ }^{23}$ O Trabalho de Direção do Comitê Central, Voz Operária, n. 77, julho de 1971, p. 124.
} 
educação e ação individual. U ma das formas de pensar a educação no interior do PCB era a de propagar as ideias comunistas por meio de reuniões com militantes, que ao mesmo tempo em que educavam, conscientizavam os trabalhadores e demais segmentos sociais, conforme observamos no $A$ becedário dos trabalhadores.

E's pobres? E's um trabalhador? Pois reúne num domingo, em tua casa, três ou quatro companheiros de trabalho; lêerelêestas linhas; discute com eles o que te digo. Faze com que cada um deles proceda da mesma forma. Espalha o mais possível esteA becedário, que é teu, que é o abecedário dos trabalhadores; publica o maior número possível de jornais; manda imprimir milhares de exemplares e os espalha entre os trabal hadores das fábricas, usinas, engenhos, fazendas, oficinas. Mete essas idéias na cabeça dos milhões de trabalhadores deterra e mar; trava discussões em torno delas, em toda a parte - nas cidades industriais, nos grandes navios que fazem a viagem para a Europa, nas jangadas dos praieiros do N orte, no meio dos seringais, na catinga cheia de vaqueiros, nos altos sertões, na rica zona da mata, nos pinheirais e coxilhas do Sul, nos garimpos de Minas Gerais, nas minas de ouro e carvão de pedra. É de teu interesse, é para teu benefício (FA V ORETO, 2010, p. 138).

O que fica claro nessa passagem é que, para o PCB, a educação tinha como principal função despertar a consciência dos trabalhadores para as contradições que a sociedade brasileira apresentava, permitindo assim a proposição de uma nova ordem, mais condizente com as necessidades da classe trabalhadora, na qual as liberdades democráticas fossem respeitadas. A ssim, uma das principais tarefas do partido comunista e de seus militantes era divulgar as ideias comunistas junto ao povo brasileiro, uma vez que a revolução só seria possível a partir dos ensinamentos da teoria marxista que impulsionou as diversas revoluções na Europa e na A mérica Latina. As ideias de educação como um campo de resistência, que permitiria a mudança da conjuntura nacional, influenciaram intelectuais e estudantes em diferentes regiões do país. Mesmo nos recantos mais longínquos tais ideais tiveram penetração, em A quidauana - interior do então Mato Grosso- eles também se fizeram presentes por meio da ação do professor Ênio Cabral que atuou fortemente na busca de uma educação emancipadora. Dessa forma, ao analisar as concepções de educação expressas nos documentos do PCB, percebemos que existia uma convergência entre elas ea visão de Enio Cabral, que buscava, por meio da educação, debater os assuntos da conjuntura nacional e internacional com seus alunos, motivando-os a observar as contradições da sociedade e despertar sua consciência crítica. Sua ação visava uma educação transformadora que se iniciaria na escola e

OMES, A. K. Estudantes e intelectuais do FCB: a luta por liberdades demoeráticas durante a ditadura.

albuquerque: revista de historia. vol. 9, n. 17, jan.-jul. de 2017, p. 94-116 
extrapolaria esse espaço, permitindo assim, quem sabe, uma sociedade mais justa e igualitária. Contudo, o golpe de Estado de 1964 impediria que seu projeto e do PCB se realizasse num curto prazo.

\section{enio cabral e sua utopia revolucionária}

Enio Cabral, embora não visse nos idos de 1964 a chance de uma revolução radical que implementasse o socialismo no país, acreditava sim na possibilidade de mudanças sociais que pudessem transformar a sociedade brasileira ecriar condições mais justas e igualitárias para os trabalhadores. Leite chama a atenção para a localização fronteiriça Brasil-Paraguai de A quidauana e intui queseria esse o motivo de a cidade ter despertado a aten ção dos militares, em face da preocupação com a segurança nacional e com a repressão ao comunismo. 0 autor compõe também o cenário que permitiu entender a singularidade da instauração da ditadura civilmilitar na pequena A quidauana, que, segundo ele, possuía uma tradição autoritária:

Por meio da história de A quidauana, o leitor poderá perceber que a utopia e a Repressão estiveram alicerçadas em um passado definido. Esse passado foi o do autoritarismo, o da violência e o do poder privado fazendo às vezes da presença estatal. Os coronéis, corpos vivos da oligarquia, foram os verdadeiros senhores da região pantaneira durante longos anos. A quidauana não foi exceção (LEITE, 2009, p. 14).

N um trabal ho minucioso ecom uma documentação instigante, o historiador parte da discussão de um conceito que nos parece extremante importante nos dias de hoje, em que enfrentamos a capitulação frente à possibilidade de uma sociedade mais justa - a utopia. Consideramos tal conceito na perspectiva apontada pelo filósofo Hebert Marcuse:

Iniciando por uma verdade óbvia, direi que hoje qualquer forma nova de vida sobre a terra, qualquer transformação no ambiente técnico e natural, é uma possibilidade real, que tem seu lugar próprio no mundo histórico. Podemos fazer do mundo um inferno (.). Mas podemos fazer também o oposto. Este fim da utopia, ou seja, a recusa das ideias e das teorias queainda se servem de utopias para indicar determinadas possibilidades históricosociais, podemos hoje concebêlo, em termos bastante precisos; também como o fim da história; isto é, no sentido de que as novas 
possibilidades de uma sociedade humana e de seu ambiente não podem mais ser imaginadas como prolongamento das velhas, nem tão pouco serem pensadas no mesmo continuum histórico (MARCUSE, 1969, p.14-15).

A perspectiva de interpretação mais correntea respeito do conceito de utopia quer postulála como algo incongruente com a solução dos problemas da realidade, uma vez que ele designa o regime social, econômico e político que, por ser perfeito e ideal, não pode ser encontrado em nenhum lugar. Para Marcuse, ao contrário, a utopia é precisamente aquilo que ainda não se realizou, e não algo irrealizável${ }^{24}$.

Para sustentar sua premissa, Marcuse questiona o sentido da palavra irrealizável, demonstrando que geralmente ela indica al go não passível de realização, aquilo que atenta contra a realidade presentee a ordem vigente. $\mathrm{No}$ entanto, a utopia deve ser projetada como uma perspectiva futura. A ssim, certas realidades que são ilusórias no presente podem se tornar concretas em momentos futuros. As revoluções eram para ele um exemplo concreto disso. A utopia serviria então para ampliar as possibilidades de futuro, reforçando a ideia de ruptura com as velhas ideias e de combate à noção de permanência, tão comum ao campo da história.

Tomando como referência as ideias de Marcuse e Lowy, buscamos então entender Ênio Cabral : um professor comunista que acreditava "utopicamente" na possibilidade de uma revolução no país nos idos dos 1960. A o que parece, o professor Enio Cabral, militante comunista que se utilizava não só de suas aulas, mas também delugares públicos, especialmente conversas de bares, praças erodas de amigos, para

\footnotetext{
24 Para Norberto Bobbio, a tentativa de definição da utopia é complicada pela multiplicidade de aproximações possíveis. Bobbio destaca ainda que: "Na acepção mais generalizada, a utopia (política, social e tecnológica) não pretende destruir a realidade atual que aceita no que ela tem de melhor; portanto, a sociedade que ela mostra é apenas sua projeção, na qual os aspectos positivos são "maximizados". Com base nessa lógica, moveram-se tanto um literato como H. G. Wells - que chama de "cinética" a utopia moderna, estruturada não como um estado permanente - como um promissor estado intermediário de uma longa escala de níveis sucessivos - quanto um filósofo como Ernest Bloch, com sua contraposição de uma utopia concreta ao fantasiar o socialismo utopístico. Com muito mais coerência, Herbert Marcuse, considerando que a utopia esteja ultrapassada porque hoje qualquer transformação do ambiente técnico e natural é uma possibilidade real, propõe que o termo seja usado somente para designar um projeto de transformação social que esteja em contradição com leis cientificas "realmente determinadas e determinantes. Quem pode, porém, hipotecar o futuro da ciência e o futuro ainda mais longínquo da evolução da espécie? Em lugar de morrer, utopia abandona o adjetivo de 'moderna' e torna às origens. A relação com a história é incompatível com a utopia que é atemporal. A Utopia de Bloch, de Wells, de Marcuse não tem suas raízes nos modelos clássicos de regeneração, mas na antiga alma semítica dos profetas bíblicos, enquanto a outra - contestadora da realidade existente e enraizada nas próprias instâncias - nasce do ódio cristão contra a natureza corrupta, mas desenvolve-se em contraste com a resignação religiosa, visando uma palingenesia toda terrena, o que, porém, não significa que esteja limitada ao simples bem-estar material. (Marx, profeta da 'História Prometida' como saída para a préhistória, na qual ainda vivemos, pode validamente exemplificar esta posição" (BOBBIO, Norberto; MATEUCCI, Nicola; PASQUINO, Gianfranco. Dicionário de política (volume 2). Trad. Carmen C. Varrialle et al.; coord. de trad. João Ferreira, rev. geral: João Ferreira e Luis Guerreiro Pinto Cacais. - Brasília: Editora Universidade de Brasília, 9 ed., 1997. Vol. 2. 656, p.1286)
}

\footnotetext{
GuMES, A. R. Estudantes intelectuais do FCB: a luta por liberdades democráticas durante a ditadura.

albuquerque: revista de historia. vol. 9, n. 17, jan.-jul. de 2017, p. 94-116
} 
se contrapor ao regime militar, também partilhava da visão utópica de Marcuse; por essemotivo foi o principal mentor de atividades políticas queaterrorizavam as elites em A quidauana.

Segundo a historiadora Suzana A rakaki (A RAKA KI,2003) em Dourados a perseguição dos militares não se limitou apenas aos colonos da CAND e aos militantes do PTB, dirigiu-se também aos trabalhadores do magistério, constantemente vigiados pelo regime para evitar que críticas fossem feitas durante suas aulas. Muitos dos professores eram vigiados pelos próprios colegas, que, como mencionei anteriormente, eram cooptados em troca de cargos e benefícios. A exemplo do que ocorria em Aquidauana, o patrulhamento ideológico sobre os professores era feito sem maiores rodeios, principalmente por parte de alunos e pais de alunos que reportavam aos diretores qualquer conduta inadequada de seus professores. U m jornal da época, citado pela pesquisadora, nos dá a dimensão de tal situação:

\section{COMISSÃ O DE INVESTIGAÇÃO ESCOLAR}

No dia 28/7/64 realizou-se na vizinha cidade de Ponta Porã, inquérito por uma comissão especial com elementos de Belo H orizonte, Bauru eCampinas, onde prestaram depoimentos todos os diretores de escolas de ensino médio da região sul de Mato Grosso, inclusive os diretores das escolas de Dourados, no sentido de que venham a ser afastados do magistério todos os professores portadores de idéias marxistas e subversivas. Esta comissão foi de iniciativa e oficializada pelo Ministério de Educação e Cultura. A ssim esta comissão está percorrendo o Brasil inteiro no sentido de prestar o seu trabalho a uma democracia sadia, pois milhões de alunos têm passado sob as orientações de professores comunistas, que conseguem incutir na memória de seus pupilos as mais desastrosas idéias (O Progresso, A RA KA KI, 2003, p. 92).

Observe-se que o foco da comissão era a divul gação das ideias marxistas, que eram largamente combatidas nesse período - vale lembrar que no caso de Enio Cabral, boa parte de suas obras foi confiscada pelo exército brasileiro, eal gumas delas nunca mais foram devolvidas. Naquele tempo não só em Dourados, como em outras regiões, professores eram afastados, interrogados e, muitas vezes, presos e torturados. A organização de uma resistência entre os professores era bastante difícil, pois como destacou A rakaki (2003), além da repressão, que era constante, a profissionalização dos professores era também precária, já que uma grande maioria deles, pelo menos no sul do Mato Grosso, não possuía formação acadêmica e vivia alheia aos direitos da profissão. Os contratos e nomeações quase sempre se davam

MMS, H. K. Estudantes e intelectuais do FCB: a luta por liberdades demoeráticas durante a ditadura.

albuquerque: revista de historia. vol. 9, n. 17, jan.-jul. de 2017, p. 94-116 
por apadrinhamento de autoridades locais civis e militares. A rakaki aponta que tal situação só iria se transformar com a chegada de professores oriundos dos grandes centros do país.

No caso do magistério, a situação viria a mudar anos mais tarde, com a vinda de professores de outros estados, quando o governo de Mato Grosso substituiu os professores leigos da rede estadual de ensino. A ssim, houve inserção de novas pessoas e novas idéias. Nesse processo, teve importância a criação, em 1971, do Centro Pedagógico de Dourados - CPD, unidade da U niversidade Estadual de Mato Grosso, instalado na cidade de Dourados exatamente para formar professores destinados a atuarem nas redes municipais e estadual de ensino. A lguns professores vindos de outros estados, que já estavam trabal hando na rede estadual, passaram também a ministrar aulas no Centro (A RAKA KI, 2003, p. 94).

O Centro Pedagógico de Dourados também foi alvo de patrulhamento ideológico. Dirigido por um advogado apoiador do regime militar, o referido centro passou a ser um reduto de apadrinhamento de professores, e os que fizessem críticas à direção ou algum aspecto do regime eram sumariamente demitidos. Segundo A rakaki (2003), na década de 1970 diversos professores foram demitidos da instituição. Dentre eles destacam-se Ivan A parecido Manoel, que hoje leciona na UNESP, e José Luiz Sanfelice, atualmente na UNICAMP. A demissão dos professores gerou insatisfação entre os colegas e alunos, que buscaram todas as medidas legais para readmissão dos mesmos - isso acabou forçando o pedido de demissão do diretor da CPD. Os professores A ntonio Luiz Lachi eW ilson V alentin Biasotto foram readmitidos posteriormente, mas tiveram que abrir mão das indenizações a que teriam direito pelo período que ficaram afastados.

A perseguição aos professores no interior das universidades brasileiras foi relatada no relatório da Comissão $\mathrm{N}$ acional da $\mathrm{V}$ erdade (CNV ), no qual encontramos várias referências a afastamentos, demissões e ainda a interferência em projetos e linhas de pesquisa em diferentes universidades do país.

Os relatores no texto temático sobre a ditadura nas universidades federais informam que:

A lém das cassações (reitores e professores), outro instrumento amplamente utilizado pelos militares foram os Inquéritos PolicialMilitares (IPM). V ários IMPS foram abertos ainda no mês de abril de 1964, para investigar entidades associativas, como a UNE, instituições de ensino e pesquisa como o Instituito Superior 
de Estudos Brasileiros (ISEB), e partidos, como o PCB (Relatório da Comissão Nacional da V erdade, 2014, p. 269).

Hoje sabemos, a partir do avanço das pesquisas no campo da história da educação, que a vigilância e a violência contra os professores não se limitaram apenas às universidades brasileiras, mas chegaram às salas de aulas do ensino fundamental e médio em várias regiões do país. Em reportagem de $O$ Globo, publicada em 2014, encontramos informações de que o controle da educação básica no país não se deu somente pela perseguição dos profissionais com histórico de militância; ele se voltou para um controle mais amplo, que incluía o controle dos conteúdos ministrados por todos os professores. 0 exemplo da introdução de disciplinas como OSPB (Organização Social e Política Brasileira) e EMC (Educação Moral e Cívica), através do Decreto-Lei n. 869, de 12 de setembro de 1969, demonstra isso. Segundo um dos professores entrevistados pelo jornal $O$ Globo, havia uma autocensura, pois muitas vezes os próprios funcionários da escola atuavam como delatores dos colegas. Foi o que aconteceu com ele em 1969.

Em 1969, A ntônio Rodrigues já tivera um exemplo não só da repressão contra escolas, mas dentro das próprias: "uma autocensura que era talvez pior". Ao vê-lo debatendo sobre músicas deum LP de Geraldo V andré com alunos do $2^{\circ}$ grau, uma orientadora educacional do Centro Educacional de Niterói (CEN) disse à direção do colégio que o professor A ntônio estaria fazendo "proselitismo político", pois falava com os alunos de música "proibidas". Ele foi demitido imediatamente (O Globo, 17/03/2014).

0 quadro apontado pela Jornalista A lessandra Duarte no jornal $O$ Globo coincide com a situação vivenciada pelas escolas do sul do Mato Grosso, onde, por meio das fontes pesquisadas, pudemos perceber que a vigilância foi grande, não só sobre os professores, mas também no que se refere aos conteúdos 25 . Dal piaz (2008) trata da perseguição de professores das áreas de ciências humanas em Campo Grande, e o resultado de seu estudo demonstra que o medo era sempre uma constante nas falas de seus entrevistados. Segundo ele, nesse contexto buscava-se driblar a censura e os censores dentro e fora de casa, nos encontros clandestinos,

25 Sobre as reformas curriculares ocorridas no contexto da ditadura militar consultar os autores: NUNES, Silma do Carmo. Concepções de mundo no ensino de História. 2 ed. Campinas: Papirus, 2002; FONSECA, Selva Guimarães. Caminhos da História Ensinada. Campinas: Papirus, 1993; MUNAKA, Kazumi (2001). História que os livros didáticos contam, depois que acabou a ditadura no Brasil. In M. C. Freitas (org.), Historiografia brasileira em perspectiva. São Paulo, Contexto, pp. 271-298; BITTENCOURT, C. M. F (Org.). O saber histórico na sala de aula. 2. ed. São Paulo: Contexto, 1998. 
nas leituras proibidas, nos programas de rádio que ouviam, pois tinham a impressão de serem vigiados o tempo todo.

Enio Cabral, professor de História do Brasil do Colégio Cândido Mariano, enfrentou diversos problemas de censura, sendo acusado por colegas, alunos e pais de alunos de desviar os assuntos de sua disciplina para a promoção do comunismo. Certamente por esse motivo um dos primeiros inquéritos montados na cidade foi contra ele, que foi preso no dia 04 de abril de 1964, cinco dias após o golpe. Enio foi considerado pelos representantes do Estado na cidade como inimigo número um da segurança nacional, não só por conta de sua atuação como docente, mas principalmente por atividades à frente do PCB. Foi provavelmente por esse motivo que o referido professor se tornou o principal alvo da repressão militar logo no início do regime. Logo nos primeiros dias de implantação do regime o Ênio Cabral foi preso e interrogado pelos militares, tendo sofrido inclusive torturas psicológicas e físicas, conforme se apresenta nos autos do (IPM) Inquérito Policial Militar disponível no Fórum de A quidauana.

Encontramos no próprio auto de interrogatório constante no processo informações sobre as torturas sofridas, que foram narradas quando da transformação do IPM em processo-crime. A ssim relatou o réu ao juiz de direito H eliophar de Almeida Serra, quando questionado se mandou queimar documentos que comprovassem sua ligação com o partido comunista local:

Que não é verdade que tivesse pedido que sua família queimasse documentos de caráter comprometedores que se encontram em uma pasta em sua casa; Precionado que foi durante o IPM, acabou confessando o quenão eraverdade.Que declarou no IPM.quenão pagava mensalidade ao Partido Comunista, mas sim de quanto em vez remetia a importância de cem cruzeiros as redações que lhe mandavam jornais, porem que 0 encarregado do IPM. forçava dizer que 0 acusado pagava mensalidades. Que anteriormente no depoimento que prestou no IPM e durante o mesmo, o acusado várias humilhações e maus tratos, castigos corpóreos, ameaças, por parte de alguns A spirantes (sic) (IPM , Ênio de Castro Cabral, fl. 60).

Em outro trecho do depoimento, as torturas físicas eram mais explícitas e graves, conforme relatou Ênio Cabral:

Que numa dessas vezes quanto foi chamado uma sala (biblioteca) um aspirante apontou uma metralhadora contra a cabeça de acusado; noutra ocasião, duranteo interrogatório a portas fechadas, e quando se encontrava sentado em uma cadeira, um aspirante subiu no pescoço do acusado; em quanto ensaiava um

GoMes, A. R. Estudantes e intelectuais do FCB: a luta por liberdades demoeráticas durante a ditadura. 
estrangulamento enrolando uma camiseta no pescoço do acusado. Que várias vezes foi obrigado a permanecer de joelhos; que em outra ocasião, quando dava sua interpretação sobre a figura de Jesus Cristo, recebeu um soco no nariz; que em outra ocasião foi levado a noitenuma das Baias do quartel, quando agarrado por dois soldados de porte avantajado, teve a braguilha da calça aberta e retirados o seu membro e o escroto, ensaiando-se uma como que castração do acusado (sic) (IPM, Ênio de Castro Cabral, fl. 61).

A lém das psicológicas, Ênio Cabral também sofreu torturas físicas que objetivavam arrancar-Ihe à força confissões sobre sua ligação com o partido comunista, bem como suas atividades subversivas na cidade de A quidauana:

(.) fizeram-no subir a uma arvore, dizendo-lhe que era um macaco soviético, disparando em torno da arvore alguns tiros de pistola; Que esses fatos se passaram em uma noite muito escura e chuvosa; Que nessa noite sendo obrigado a sair quando já se preparava pra dormir, estava descalço, e quando quiz por os sapatos, ordenaram-lhe que saísse descalço mesmo; Por isso, tendo andado descalço sobre o cascalho, praticando as ações já referidas, por vezes puchado pelos dois soldados, acabou tendo a planta do calcanhar esquerdo deslocada, pelo que no dia seguinte o Cap. Médico da Unidade, depois de examinar o acusado, mandou que o enfermeiro 0 atendesse; Que em vista dessas torturas, inclusive morais, infligidas ao acusado, as suas declarações constantes de Fls. 41 e 43 do I PM, não refletem a verdade em numerosos pontos (sic) (IPM, Ênio de Castro Cabral, fl. 61).

A partir do trecho acima, percebese que a tortura tinha uma função essencial dentro do sistema autoritário implantado em A quidauana nos idos de 1964. Ela constituía uma ferramenta de interrogatório e controle de presos, visando a obtenção de confissões forçadas ou punição extrajudicial de desobediências, ou seja, antes mesmo do julgamento o réu já pagava fisicamente por seus supostos atos criminosos. Se estabelecermos um comparativo com a sociedade atual, em que muito se fala sobre a implantação de normas mais rígidas para punição de crimes, chegando inclusive a se cogitar a pena de morte, perceberemos que pode ser um resquício da ditadura.

A ssim sendo, podemos acreditar que para um certo grupo da sociedade, sobretudo no período da ditadura, a tortura e a execução sumária de parcelas não desprezíveis da população, tais como estudantes, professores, comunistas, guerrilheiros, sindicalistas eagitadores, poderiam ser vistas como punições paralelas "merecidas" pelos suspeitos e condenados. Se encontramos argumentos no seio da

GOMES, A. K. Estudantes e intelectuais do FCB: a luta por liberdades democráticas durante a ditadura.

albuquerque: revista de historia. vol. 9, n. 17, jan.-jul. de 2017, p. 94-116 
população brasileira, que é omissa ou conivente com esses atos, o que dizer da aceitação de uma confissão forjada com vistas à condenação de um comunista e agitador? Muito provavelmente os militares que empreendiam tais atos encontravam respaldo na ideia de quefaziam isso em prol deuma causa maior, qual seja: proteger a sociedade da ameaça comunista! Também muito provavelmente esses soldados encontravam respaldo no apoio familiar, pois certamente possuíam mães, pais, esposas e filhos que viviam alheios aos seus atos, ou simplesmente não davam importância a eles, uma vez que eram necessários para proteger a nação brasileira. A pesar da luta de estudantes e professores, como Ênio Cabral, o imaginário brasileiro ainda é povoado por dor e silêncios. 